Provided for non-commercial research and education use. Not for reproduction, distribution or commercial use.

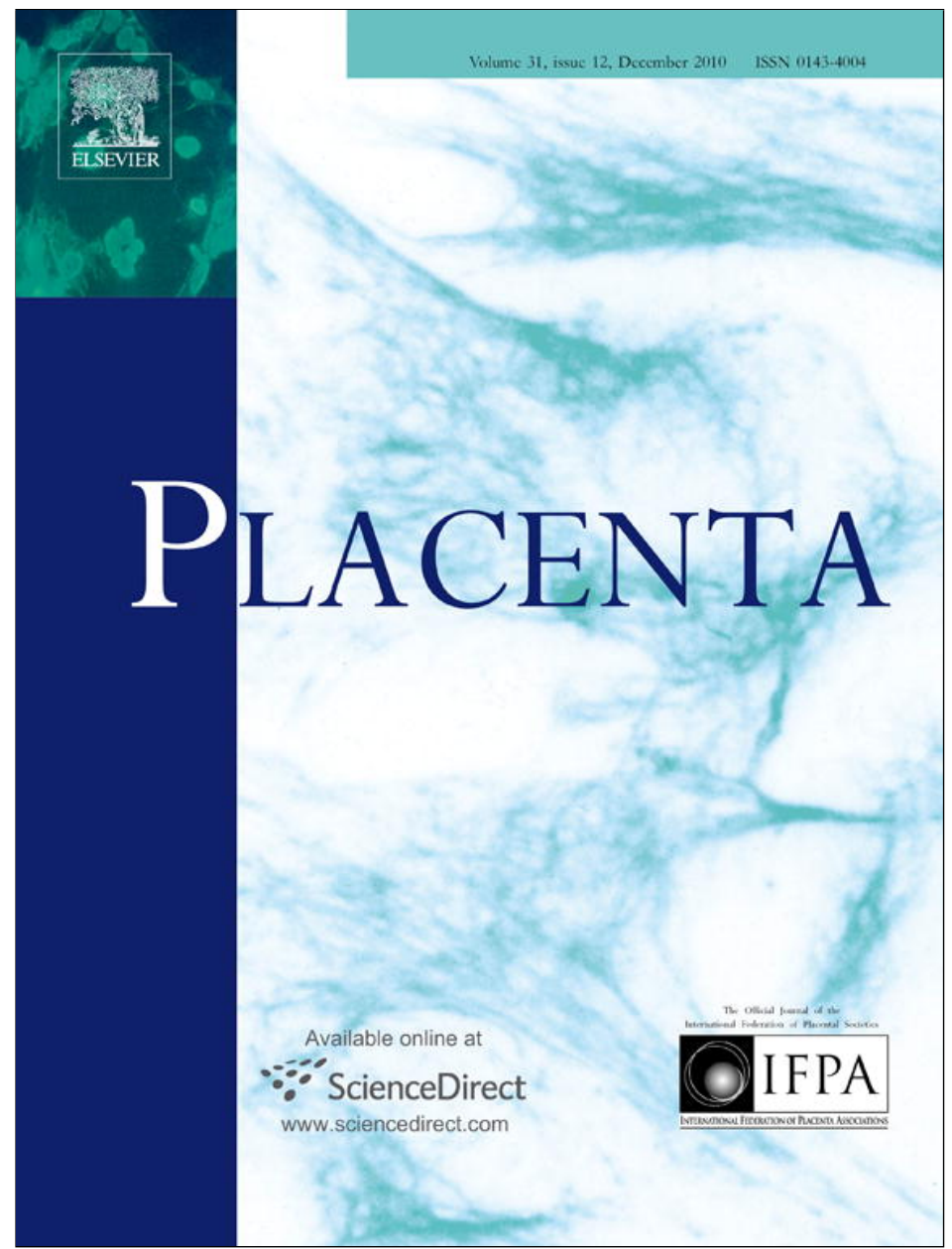

This article appeared in a journal published by Elsevier. The attached copy is furnished to the author for internal non-commercial research and education use, including for instruction at the authors institution and sharing with colleagues.

Other uses, including reproduction and distribution, or selling or licensing copies, or posting to personal, institutional or third party websites are prohibited.

In most cases authors are permitted to post their version of the article (e.g. in Word or Tex form) to their personal website or institutional repository. Authors requiring further information regarding Elsevier's archiving and manuscript policies are encouraged to visit:

http://www.elsevier.com/copyright 


\title{
Placental Effects of Systemic Tumour Necrosis Factor- $\alpha$ in an Animal Model of Gestational Diabetes Mellitus
}

\author{
R.A. Bobadilla ${ }^{a, b}$, R. van Bree ${ }^{a}$, L. Vercruysse ${ }^{a}$, R. Pijnenborg ${ }^{a}$, J. Verhaeghe ${ }^{a, *}$ \\ ${ }^{a}$ Department of Obstetrics and Gynecology, Health Campus Gasthuisberg, Katholieke Universiteit Leuven, 3000 Leuven, Belgium \\ ${ }^{\mathrm{b}}$ Escuela Superior de Medicina del Instituto Politécnico Nacional, Mexico City 11340, Mexico
}

\section{A R T I C L E I N F O}

\section{Article history:}

Accepted 28 September 2010

\section{Keywords:}

Apoptosis

Gestational diabetes mellitus

TNF

Trophoblast invasion

Uterine natural killer cells

\begin{abstract}
A B S T R A C T
Background: Gestational diabetes mellitus (GDM) may adversely affect fetoplacental interaction. Numerous reports demonstrate that GDM women have increased circulating tumour necrosis factor$\alpha$ (TNF), a pro-apoptotic peptide.

Objective: To examine whether implantation site apoptosis is increased by exogenous TNF in mice heterozygous for a defective leptin receptor $(d b /+)$, a GDM animal model.

Study design: Implantation sites were studied at gestational day (gd)18.5 in 3 groups: saline-treated wildtype $(w t)$ and $d b /+$ mice, and TNF-treated $d b /+$ mice. Saline or TNF (total dose $4 \mu \mathrm{g}$ ) was administered by miniosmotic pump from gd11.5. Immunostaining for cleaved caspase-3, PAS and cytokeratin was performed for quantification of apoptotic cells, uterine natural killer (UNK) cells, and trophoblast invasion, respectively. The mRNA expression of TNF and TNF-induced apoptotic markers in placenta and mesometrial triangle (MT) was measured by quantitative RT-PCR.

Results: The implantation sites from saline-treated $w t$ and $d b /+$ mice showed comparable numbers of apoptotic cells and uNK cells. Compared with the saline-treated groups, TNF-treated $d b /+$ dams had less fetuses; the placental labyrinth and trophospongium contained more apoptotic cells; and the MT contained a higher total number of uNK cells including more cells intensely stained for cleaved caspase- 3 as well as cells with negative staining. Trophoblast invasion was shallower in $d b /+$ than in $w t$ mice $(14 \%$ and $30 \%$ of total invasion into MT, respectively) but this was not affected by TNF. The mRNA expression of TNF and apoptotic markers was comparable in the 3 groups.

Conclusions: TNF treatment in $d b /+$ mice raises the number of apoptotic cells in the placenta, and appears to increase the retention of uNK cells in the MT. Db/+ mice demonstrate shallower trophoblast invasion which is unaffected by exogenous TNF.
\end{abstract}

(c) 2010 Elsevier Ltd. All rights reserved.

\section{Introduction}

The prevalence of gestational diabetes mellitus (GDM) has increased in recent decades because more pregnant women are older and/or overweight [1]. Although maternal obesity and GDM are accompanied by a higher mean birth weight, emerging evidence suggests that the fetuses may not reach their growth potential [2]. In rodents, a high-fat diet worsened reproductive outcome: less

Abbreviations: AP, alkaline phosphatase; BSA, bovine serum albumin; DBA, Dolichos biflorus agglutinin; gd, gestational day; GDM, gestational diabetes mellitus; MT, mesometrial triangle; RT, room temperature; TNF, tumour necrosis factor- $\alpha$; uNK, uterine natural killer; $w t$, wild-type.

* Corresponding author. Department of Obstetrics and Gynecology, U.Z. Gasthuisberg, Herestraat 49, 3000 Leuven, Belgium. Tel.: +32 16 344212; fax: +32 16 344205.

E-mail address: johan.verhaeghe@uz.kuleuven.be (J. Verhaeghe). fetuses [3,4], lower fetal [5,6] and placental [5] weight, and placental oxidative stress [7] have been reported.

A lack of suitable animal models partly explains the paucity of studies on fetoplacental interactions in GDM pregnancies. The lowdose streptozotocin rat model has several disadvantages including the absence of maternal and fetal overweight [8]. A promising animal model for GDM is the C57BL/KSJ-Lep ${ }^{d b /+}$ mouse, also known as the Lepr ${ }^{d b /+}$ (generally abbreviated as $d b /+$ ) mouse [9]. Db/+ mice are heterozygous for a spontaneous loss-of-function mutation in the leptin receptor gene (Lepr). Whereas $d b / d b$ mice are severely diabetic/obese and sterile, the $d b /+$ counterparts show a milder phenotype and they can reproduce. In the non-pregnant state (at age 8 weeks), $d b /+$ mice show increased fat mass and insulin resistance compared with wild-type $(w t)$ mice but glucose tolerance is largely normal $[9,10]$. However, glucose tolerance is impaired during late gestation $[9,11]$, and the weight of the fetuses at term is increased by $5-8 \%$ [9-13]. 
GDM gravidas show an altered secretion pattern of adipokines (i.e., adipose tissue secretory products) with an increase in circulating tumour necrosis factor- $\alpha$ (TNF) concentrations as one of the most consistent changes [14-19]. Adipose tissue TNF expression is upregulated by the accumulation of $\mathrm{M}_{1}$ macrophages triggered by adipocyte hypertrophy [20]. In turn, TNF has been shown to induce insulin resistance $[15,21,22]$. $D b /+$ mice showed a 2.5 -fold overexpression of TNF mRNA in adipose tissue when fed a standard diet, and a $>6$-fold overexpression on a high-fat diet [10].

As a pleiotropic cytokine with a pro-apoptotic effect, excess TNF may affect placental morphology and function. Acting through the extrinsic apoptotic pathway, TNF binds to the cell surface 'death receptors' TNF receptor 1 (TNFR1) and TNFR2, and activates the effector caspase-3 [23]. Various cell types in the placenta express TNFR1 and TNFR2 [23], and high-dose TNF administration caused placental and decidual necrosis in the rat [24].

We hypothesized that TNF overexpression is one of the mechanisms that explains the deleterious effects of obesity or/and GDM on reproductive outcome. In C57BL/6 mice without $d b /+$ mutation, TNF administration during the last week of gestation (continuous s.c. release, $4 \mu \mathrm{g}$ in total) reduced fetal and placental weight at term by $5 \%$ and $7 \%$, respectively [25]. In the current study, we explored the fetoplacental effects of TNF, administered using the same protocol, in $d b /+$ mice fed a standard diet.

\section{Materials and methods}

\subsection{Animal procedures}

The study protocol was approved by the K.U. Leuven ethical committee of animal research. C57BL/KsJ-Lep ${ }^{d b /+}(d b /+)$ and the respective $w t$ mice were obtained from the Jackson Laboratory, Bar Harbor, ME, USA, and a local colony was established since 2002 [10]. The breeding program consists of $d b /+$ females and $w t$ males, thus producing $d b /+$ or wt offspring; $w t$ males are either inbred or purchased from the Jackson Laboratory to prevent extreme inbreeding. Wt mice can be recognized by their grey coat colour and white tail-end, compared to all-black $d b /+$ mice. The mice are housed in a temperature-, humidity-and light-controlled animal facility and have ad libitum access to tap water and a standard low-fat laboratory chow containing 51\% (weight/weight) carbohydrate, $3 \%$ fat and $21 \%$ protein (Trouw, Gent, Belgium).

$\mathrm{Db} /+$ and $w t$ female offspring of breeders were mated overnight at 8 weeks of age with wt males, and were weighed at gestational day (gd)0.5 (morning of copulation plug), gd7.5, gd11.5 and gd18.5. At gd11.5, an Alzet miniosmotic pump (model 2001, Charles River, L'Arbresle, France) was inserted s.c. in the nucho-dorsal midline under light ether anaesthesia. The pumps were filled with either saline (wt and $d b /+$ mice) or recombinant mouse TNF ( $d b /+$ mice only) (Promocell, Heidelberg Germany). The pump delivered $4 \mu \mathrm{g}$ TNF over 7 days, as in a previous study [25], corresponding to $100-120 \mu \mathrm{g} / \mathrm{kg}$ or $0.60-0.72 \mu \mathrm{g} / \mathrm{kg}$ h. This dose was derived from a study in rats in which $1 \mu \mathrm{g} / \mathrm{kg}$ h was infused [21]. At gd18.5, the animals underwent an insulin tolerance test in the fed state. Insulin (Humulin Regular, Eli Lilly, Indianapolis, IN, USA) at $1 \mathrm{U} / \mathrm{kg}$ was injected intraperitoneally; measurements of glucose were performed before the insulin injection and at 15, 30, 45 and 60 min after insulin injection with a glucometer (Glucocard Memory 2 Menarini, Florence, Italy) on a drop of blood obtained through a small tail snip. Subsequently, a caesarean section was performed under pentobarbitone $(8 \mathrm{ml} / \mathrm{kg}$,

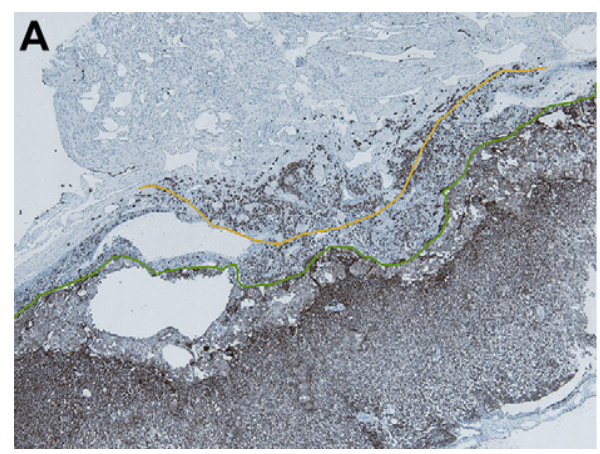

intraperitoneally) anaesthesia. The number of visible resorptions and malformed fetuses was recorded. A blood sample was obtained from the maternal aorta. The placentas and fetuses were delivered clockwise; the first placenta was weighed, the second (and fourth, if available) placentas and mesometrial tissue were individually snap frozen in liquid nitrogen and subsequently stored at $-80^{\circ} \mathrm{C}$ for RT-PCR analysis, and the third (and fifth, if available) were immersed in fixative (4\% paraformaldehyde in $0.1 \mathrm{M}$ phosphate buffer, $\mathrm{pH} 7.2$ ). All fetuses were weighed; the pump was extracted to recalculate the gd18.5 body weight.

\subsection{Implantation site histology}

The placentas were kept in fixative for $24 \mathrm{~h}$ at room temperature (RT), washed for $24 \mathrm{~h}$ at $4{ }^{\circ} \mathrm{C}$ in $0.1 \mathrm{M}$ phosphate buffer with addition of $3 \%$ sucrose, and stored in $70 \%$ ethanol at RT until further processing into paraffin blocks according to standard procedures. Three $\mu \mathrm{m}$-sections parallel to the fetal-mesometrial axis were cut from these blocks, and appropriate central sections (around the central arterial channels) were selected for analysis. Sections were double-immunostained for cleaved caspase- 3 to evaluate apoptosis, and $\alpha$-actin to differentiate between decidua and mesometrial triangle (MT); they were counterstained with the PAS method to enhance morphological detail and to visualize uterine natural killer (uNK) cell granules in pink. Two parallel sections were stained with the lectin Dolichos biflorus agglutinin (DBA) to differentiate uNK cell phenotype [26] and immunostained for cytokeratin as a trophoblastic cell marker, respectively.

2.2.1. Double immunohistochemical staining for apoptosis and smooth muscle cells

The sections were deparaffinized and heat-retrieved in citrate buffer $(10 \mathrm{mM}$, $\mathrm{pH}$ 6) for $2 \mathrm{~h}$ in a water bath set to $95^{\circ} \mathrm{C}$. First, sections were incubated overnight at $4{ }^{\circ} \mathrm{C}$ with a rabbit polyclonal antibody to cleaved caspase-3 (Cell Signaling Technology; diluted 1/100). The use of a biotinylated swine anti-rabbit antibody (Dako, Glostrup, Denmark; diluted $1 / 400,30 \mathrm{~min}$ ) followed by alkaline phosphatase (AP)-conjugated streptavidin (Roche, Mannheim, Germany; diluted 1/1000, $30 \mathrm{~min}$ ) and nitroblue tetrazolium chloride/5-bromo-4-chloro-3-indoyl phosphate toluidine salt (NBT/BCIP, Roche, Mannheim, Germany; applied for $20 \mathrm{~min}$ ) as chromogen in the AP-reaction resulted in a black-staining of apoptotic cells. Second, smooth muscle cells were detected with a mouse monoclonal antibody against $\alpha$-actin (clone 1A4, Dako; final dilution 1/180) which was complexed with the secondary antibody before application to avoid antibody-tissue cross-reaction. Thus, the detecting AP-conjugated goat anti-mouse antibody (Dako; final dilution 1/200) was mixed with anti- $\alpha$-actin for $3 \mathrm{~h}$ at RT, and the excess available binding sites on the formed complex was blocked by adding normal mouse serum (Dako; final dilution $1 / 200$ ). After a further $1 \mathrm{~h}$, sections were immediately incubated with the complex at $4{ }^{\circ} \mathrm{C}$ overnight. Histochemical detection of the bound AP with fast blue BB as chromogen (applied for $10 \mathrm{~min}$ ) resulted in light-blue staining of smooth muscle cells, as shown in Fig. 1B. Endogenous AP was destroyed by the heat in the antigen retrieval step, while before the second sequence, sections were immersed in $\mathrm{HCl}$ $(0.2 \mathrm{M})$ for $10 \mathrm{~min}$ at RT to inactivate the AP used for detection of the cleaved caspase-3. To prevent irrelevant antibody-binding, a mixture of bovine serum albumin (BSA, 2\%), non-fat dried milk (1\%) and Tween-80 (0.1\%) was applied for $15 \mathrm{~min}$ before each antibody application, and normal goat serum $(1 / 25)$ was added to this blocking mixture during the second part of the staining. Tris-buffered saline was used as rinsing and diluting buffer throughout the procedure, except for the AP reactions in which $0.1 \mathrm{M}$ tris buffers were adjusted to alkaline $\mathrm{pH}$ and $\mathrm{MgCl}_{2}$ $(10 \mathrm{mM})$ was added as a cofactor. After immunostaining, sections were treated with $0.25 \% \alpha$-amylase from Bacillus subtilis (Sigma-Aldrich, Bornem, Belgium) during $10 \mathrm{~min}$ at $37^{\circ} \mathrm{C}$ to digest all glycogen. The sections were counterstained with the PAS method, and mounted in glycerin jelly.

\subsubsection{Lectin staining of $u N K$ cells}

After inactivation of endogenous AP activity with $\mathrm{HCl}(0.2 \mathrm{M})$ for $10 \mathrm{~min}$ at RT and blocking of irrelevant lectin binding with $4 \%$ BSA-biotinylated DBA lectin (Vector

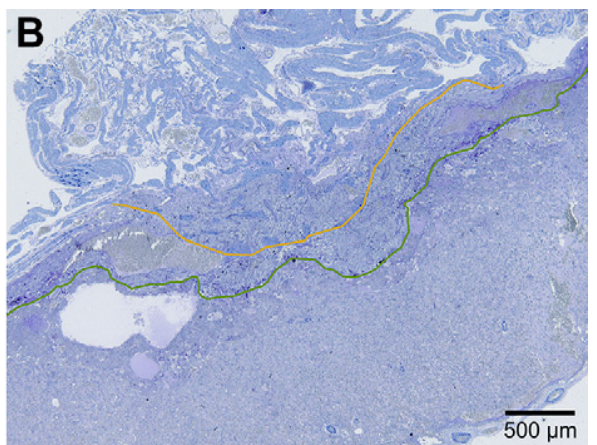

Fig. 1. A. Overview of the implantation site of a $w t$ mouse at gd18.5, showing cytokeratin-positive trophoblast invasion in maternal tissues (decidua and MT). B. Parallel section stained for cleaved caspase- 3 and $\alpha$-actin, counterstained with PAS. Delineations show the trophospongium-decidua border (dark green) and decidua-MT border (yellow). 
Table 1

General data of saline-treated $w t$ and $d b /+$ mice and TNF-treated $d b /+$ mice.

\begin{tabular}{|c|c|c|c|c|}
\hline & $\begin{array}{l}\text { wild-type saline } \\
(N=9)\end{array}$ & $\begin{array}{l}d b /+ \text { saline } \\
(N=9)\end{array}$ & $\begin{array}{l}d b /+\mathrm{TNF} \\
(N=6)\end{array}$ & $p$ \\
\hline Body weight gd 0.5 (g) & $20.16(0.52)$ & $22.34(0.63)^{\mathrm{a}}$ & $21.96(0.45)$ & 0.022 \\
\hline Body weight gd $18.5(\mathrm{~g})$ & $33.37(1.08)$ & $36.52(1.04)^{a}$ & $33.18(0.70)^{\mathrm{b}}$ & 0.049 \\
\hline Weight gain gd $11.5-18.5(\mathrm{~g})$ & $8.96(0.62)$ & $9.23(0.64)$ & $6.79(0.60)^{\mathrm{a}, \mathrm{b}}$ & 0.040 \\
\hline $\mathrm{N}$ live fetuses & $6.6(0.4)$ & $6.7(0.5)$ & $5.0(0.5)^{\mathrm{a}, \mathrm{b}}$ & 0.047 \\
\hline $\mathrm{N}$ resorptions & $1.3(0.4)$ & $0.6(0.2)$ & $0.2(0.2)$ & 0.45 \\
\hline Weight top left placenta (mg) & $104(2)$ & $95(3)$ & $105(6)$ & 0.14 \\
\hline Fetal weight (mg) & $864(166)$ & $1162(48)$ & 908 (187) & 0.25 \\
\hline Basal blood glucose (mg/dl) & $97(2)$ & $87(5)$ & $100(6)$ & 0.12 \\
\hline ITT: glucose $15^{\prime}$ (\% of basal) & $73(8)$ & $104(10)$ & $91(7)$ & 0.068 \\
\hline Glucose $30^{\prime}$ (\% of basal) & $68(8)$ & $107(16)$ & $89(11)$ & 0.10 \\
\hline Glucose $45^{\prime}$ (\% of basal) & $75(9)$ & $86(18)$ & $86(11)$ & 0.77 \\
\hline Glucose $60^{\prime}(\%$ of basal $)$ & $72(8)$ & $90(17)$ & $90(13)$ & 0.51 \\
\hline
\end{tabular}

The data are presented as means (SEM). Statistical analysis.

a Statistical analysis indicates a significant difference $(p<0.05)$ from the $w t$ saline group.

b Statistical analysis indicates a significant difference $(p<0.05)$ from the $d b /+$ saline group.

Laboratories, Burlingname, U.S.A.; diluted 1/1000) was applied for $2 \mathrm{~h}$ at RT. The bound biotin was detected with AP-conjugated streptavidin (Roche, Mannheim, Germany; diluted 1/1000, $30 \mathrm{~min}$ ) and subsequently NBT/BCIP (Roche) served as a chromogen in the AP-reaction which was run for $18 \mathrm{~min}$. Tris-buffered saline with addition of $1 \mathrm{mM} \mathrm{CaCl} 2$ was used as rinsing buffer and the same buffer with addition of $4 \%$ BSA was used for dilutions. Sections were $\alpha$-amylase-digested before counterstaining with PAS as in the cleaved caspase-3 protocol

\subsubsection{Immunohistochemical staining of trophoblast}

After endogenous peroxidase quenching in $0.5 \% \mathrm{H}_{2} \mathrm{O}_{2}$ in methanol for $30 \mathrm{~min}$, and retrieval of antigenic epitopes for $10 \mathrm{~min}$ at $37^{\circ} \mathrm{C}$ in $0.04 \%$ pepsin (P7012, Sigma-Aldrich) diluted in $\mathrm{HCl}(0.01 \mathrm{M})$, sections were exposed for $2 \mathrm{~h}$ to polyclonal rabbit anti-bovine keratin (Dako, Glostrup, Denmark; diluted 1/1500). Antibodies were detected with peroxidase-conjugated goat anti-rabbit immunoglobulins (Jackson Immunoresearch Laboratories, West Grove, PA; diluted 1/100, $30 \mathrm{~min}$ ) to which normal mouse serum (Dako; $1 / 25$ ) was added to prevent antibody binding to the tissue. Peroxidase activity was detected with $3,3^{\prime}$-diaminobenzidine tetrahydrochloride (DAB, Sigma-Aldrich) according to standard procedures. Sections were counterstained with Harris hematoxylin, dehydrated and mounted in Depex (BDH, Poole, England).

\subsubsection{Image analysis}

All materials and software were obtained from Carl Zeiss (Zaventem, Belgium). Using an Axioskop 50 microscope fitted with an Axiocam MRc5 colour-camera, overview images (objective $10 \times$, resolution $1292 \times 968$ pixels) were taken (Axiovision-panorama software module); the KS400 software was used for quantitative image analyses.

Apoptosis evaluation was performed in four manually delineated compartments of the implantation site: placental labyrinth, placental trophospongium, MT, and the part of the decidua underlying the MT; their respective area was measured. All cells positive for cleaved caspase- 3 in each compartment were manually counted, and expressed as apoptotic cells per $\mathrm{mm}^{2}$ of appropriate compartment area.

PAS-positive uNK cells in the delineated decidua and MT were counted and stratified according to their staining for cleaved caspase-3: negative (bright-pink PASpositive granules, clear cytoplasm); lightly positive (light-brown stained cytoplasm); intensely positive (black-staining which tended to blur the pink of the granules). In addition, DBA-positive and DBA-negative uNK cells were counted per compartment.

For evaluation of trophoblast invasion, the trophospongial-decidual border (between both ends of Reichert's membrane) and the decidual-MT border (covering the complete extension of the invading trophoblast) were manually traced (Fig. 1A). Trophoblast invasion was then analyzed as described [27]. Briefly, a binary image was created after segmentation of the cytokeratin-positive area. Submitting this binary image to an automated image analysis operation called "close" (size 7, number 10), a second binary image was generated in which (near-) adjacent positive regions connect to form a closed area (thus excluding isolated positive cells). This area can be taken as a measure of invasion extension, and is further named "extent". Combining the cytokeratin-positivity image and the extent image, respectively, with the respective border delineations according to Boolean rules allowed us to differentiate between the decidual and MT parts of the invaded area, and to measure the length of the overlap between the respective delineated borders and the invaded area. From these data, appropriate percentages were calculated for each section. In this evaluation, we did not differentiate between interstitially and endo-/perivascularly invaded trophoblast.

\subsection{Quantitative RT-PCR}

Hardware (ABI 7000 sequence detector), software and materials were obtained from Applied Biosystems (Lennik, Belgium). RNA was extracted with TriPure (Roche,
Mannheim, Germany) from 50 to $100 \mathrm{mg}$ homogenized placenta tissue (2-3 placentas per animal, i.e., 19 samples from saline-infused $w t$ mice, 18 from salineinfused $d b /+$ mice and 11 from TNF-infused $d b /+$ mice, respectively) and mesometrial tissue (pooled per 1-2 animals, i.e., 5 samples from both saline-infused $w t$ mice and saline-infused $d b /+$ mice, and 3 samples from TNF-infused $d b /+$ mice). The RNA concentration was determined spectrophotometrically (ND-1000; Nanodrop, Wilmington, DE, USA). The reverse transcription and PCR quantification were performed as described previously for mouse tissues in detail [28]. We measured the mRNA expression of TNF (assay ID: Mm00443258_m1), TNFRSF-1A associated via death domain (gene name) or Tradd (gene symbol) (assay ID: Mm01251029_m1), TNF receptor-associated factor 2 or Traf2 (Mm00801978_m1), and Fas(TNFRSF6)associated via death domain or Fadd (Mm00438861_m1). Tradd, Traf2 and Fadd are three key molecules in the signaling apoptotic pathway mediated through TNFR1 or/ and TNFR2 [23]. For all target genes, 18s rRNA primers and Vic-Tamra probe were used as endogenous reference. A validation experiment was completed to confirm equal PCR efficiency for each target gene and reference. We also confirmed a comparable expression of 18s RNA in placenta and mesometrial tissue from the 3 study groups.

\subsection{Data analysis}

The Prism software for Windows version 5.0 (Graphpad software, San Diego, CA, USA) was used. Continuous variables from the 3 groups were compared using oneway ANOVA; if $p<0.05$, Bonferroni's post hoc test was applied to compare the individual groups. Categorical variables were compared using the chi-square test.

\section{Results}

\subsection{General data (Table 1)}

Saline-treated $d b /+$ dams weighed more than $w t$ dams at gd0.5 and throughout gestation $(p<0.05)$, but their weight gain between gd11.5 and gd18.5 was not different from that observed in $w t$ dams. However, TNF-treated $d b /+$ dams gained less weight than both saline-treated $w t$ and $d b /+$ mice between gd11.5 and gd18.5 $(p<0.05)$. They were pregnant with less live fetuses than salinetreated $w t$ and $d b /+$ mice, but the number of visible resorptions was not different. There was 1 visibly malformed fetus in the saline $d b /+$ group and none in the other groups. No significant differences were observed among the groups in the non-fasting baseline blood glucose level or the hypoglycaemic response to exogenous insulin; however, $d b /+$ dams tended to be more insulin-resistant than $w t$ dams at the 15 and 30 min time-points $(p<0.11)$, but there was no difference between saline- and TNF-treated $d b /+$ dams.

\subsection{Histological quantitative analysis of placenta}

The total placental area, albeit not significantly different among the groups, tended to be larger in saline-treated $d b /+$ mice compared with their wt counterparts while the relative areas of labyrinth and trophospongium (as \% of total placenta) remained 
unchanged (Table 2). In the TNF-treated $d b /+$ mice, on the other hand, the total placental area was slightly lower than in the salinetreated $d b /+$ mice, owing to a smaller labyrinthine area as reflected in the (not significantly different) percentage data. The ANOVA analysis for the decidual area showed a $p$ value of 0.081 , and for the MT area a $p$ value of 0.15 (data not shown).

The number of apoptotic cells per relevant area was increased three- to five-fold in the labyrinth, trophospongium and MT, but not in the decidua, of TNF-treated $d b /+$ mice compared with the saline groups (labyrinth: $p<0.001$; trophospongium: $p<0.01$; MT: $p<0.05 v s$. $d b /+$ and $p<0.01 v s$. $w t)$. Fig. 2 shows a labyrinthine region from a TNF-treated $d b /+$ mouse with multiple apoptotic cells. Based upon the parallel keratin-stained section, most of these apoptotic cells were localized in the labyrinthine (fetal) stroma. Such areas containing apoptotic cells appeared at the fetal side of the labyrinth and were observed more frequently in the TNFtreated $d b /+$ mice. In addition, solitary apoptotic cells of different sizes were observed throughout the labyrinth in the three groups. Although some of these cells clearly belonged to the cytotrophoblastic layer lining the maternal vascular space, the complexity of the tissue did not allow identification of many apoptotic cells.

\subsection{Histological quantitative analysis of placental bed}

In the decidua, there was no difference among the 3 groups in the number of uNK cells nor in their staining intensity for cleaved caspase-3 (data not shown). In the MT, however, the uNK cell number relative to the compartment area was higher in the TNF-treated $d b /+$ mice compared with the saline groups (ANOVA: $p<0.01$ and $p<0.01$ compared with $w t$ ) (Fig. $3 \mathrm{~A}$ ). There was a higher number of uNK cells unstained for cleaved caspase- 3 compared with salinetreated $w t$ mice $(p<0.05)$ as well as a markedly higher number of intensely-stained cells compared with both saline-treated groups $(p<0.001)$ (Fig. 3B). Fig. 4 shows an area in the MT from a TNF-treated $d b /+$ mouse with multiple uNK cells, several of which are apoptotic. No differences were detected in the relative fraction of DBA-positive (between 60 and 70\%) uNK cells in the decidua among the 3 groups (ANOVA: $p=0.4281$, data not shown); in the MT, the DBA-positive fraction varied between 52 and $65 \%(p=0.0418$, but no intergroup differences at the $p<0.05$ level).

The total area invaded by trophoblast was not different among the 3 groups (Table 2, extent values). However, in both saline- and TNF-treated $d b /+$ groups, $86-87 \%$ of the trophoblast invasion was restricted to the decidua compared to $70 \%$ in the saline $w t$ mice (all differences: $p<0.01$ ). The analysis of the overlap between the invasion extent and the trophospongium-decidua and decidua-MT borders, respectively, followed the same trend. While the length of these borders was not different among the 3 groups (data not shown), $d b /+$ mice showed less overlap of the decidua-MT border than $w t$ mice $(p<0.05)$. Since the length of this border was traced between the two lateral invasion margins, the difference in overlap must be the result of gaps in the invasion front crossing the borderline. Open spaces in the invaded zone may correspond to major blood vessels or necrotic areas in the decidua, while muscle bundles may also be devoid of invading trophoblast in the MT. Fig. $1 \mathrm{~A}$ shows the implantation site in a $w t$ mouse with trophoblast invasion extending over the decidua-MT border.

\subsection{Gene expression data (RT-PCR)}

No significant differences were found in the mRNA expression (relative to 18s) of TNF (ANOVA: $p=0.33$ ), Tradd ( $p=0.43$ ), Fadd $(p=0.55)$ and Traf2 $(p=0.44)$ in placental tissue of saline-treated $w t$ and $d b /+$ mice and TNF-treated $d b /+$ mice. Neither was a difference observed in the TNF $(p=0.23)$, Tradd $(p=0.54)$ and Traf2 $(p=0.20)$ mRNA expression in mesometrial tissue; Fadd expression was below the detection limit in mesometrial tissue and was therefore not analyzed.

$T N F$ was expressed to a slightly higher degree $(p=0.066)$ in placental tissue compared with mesometrial tissue in wt mice, while there was no such difference in saline-treated $d b /+(p=0.19)$ or TNF-treated $d b /+$ mice $(p=0.42)$. Tradd was expressed to a slightly higher degree in placental $v s$. mesometrial tissue in the 3 groups $(p=0.023,0.049$ and 0.075 in $w t, d b /+$ and TNF- $d b /+$ groups, respectively); and the same was true for Traf2 ( $p=0.0098$, 0.083 and 0.033 , respectively).

\section{Discussion}

\subsection{The $d b /+$ mouse model}

Maternal weight was $\sim 10 \%$ higher than in $w t$ mice throughout gestation, as reported $[10,11]$. The $d b /+$ dams also tended to be insulin-resistant, extending our previous findings in 8-weeks-old non-pregnant $d b /+$ mice [10]. Fetal weight was higher, yet the ANOVA test indicated no significant difference. "Macrosomic" fetuses are difficult to obtain in small rodent models, given their immaturity and paucity of fat tissue at birth (1-2\% fat vs. $16 \%$ in

Table 2

Morphological analysis of implantation sites of saline-treated $w t$ and $d b /+$ mice and TNF-treated $d b /+$ mice.

\begin{tabular}{|c|c|c|c|c|}
\hline & wt saline $(N=11)$ & $d b /+$ saline $(N=13)$ & $d b /+\operatorname{TNF}(N=10)$ & $p$ \\
\hline \multicolumn{5}{|l|}{ Area: } \\
\hline Total placental area $\left(\mathrm{mm}^{2}\right)$ & $8.299(0.559)$ & $9.769(0.434)$ & $8.702(0.476)$ & 0.0924 \\
\hline Total labyrinthine area $\left(\mathrm{mm}^{2}\right)$ & $6.137(0.44)$ & $7.166(0.37)$ & $5.963(0.36)$ & 0.071 \\
\hline Total trophospongial area $\left(\mathrm{mm}^{2}\right)$ & $2.162(0.19)$ & $2.603(0.18)$ & $2.739(0.22)$ & 0.112 \\
\hline Labyrinth/placenta (area \%) & $73.88(1.54)$ & $73.28(1.53)$ & $68.58(1.88)$ & 0.0698 \\
\hline \multicolumn{5}{|l|}{ Apoptosis: } \\
\hline Apoptotic cells in labyrinth $\left(\mathrm{N} / \mathrm{mm}^{2}\right)$ & $5.28(1.54)$ & $7.88(1.16)$ & $25.40(4.62)^{\mathrm{a}, \mathrm{b}}$ & $<0.0001$ \\
\hline Apoptotic cells in trophospongium $\left(\mathrm{N} / \mathrm{mm}^{2}\right)$ & $12.94(3.26)$ & $10.16(1.19)$ & $29.43(5.72)^{a, b}$ & $<0.0001$ \\
\hline Apoptotic cells in decidua $\left(\mathrm{N} / \mathrm{mm}^{2}\right)$ & $36.23(3.51)$ & $47.12(6.91)$ & $56.46(10.71)$ & 0.1911 \\
\hline Apoptotic cells in MT $\left(\mathrm{N} / \mathrm{mm}^{2}\right)$ & $37.12(10.72)$ & $52.53(12.15)$ & $108.05(21.12)^{a, b}$ & 0.0065 \\
\hline Trophoblast invasion: & $(N=9)$ & $(N=11)$ & $(N=9)$ & \\
\hline Total extent area (decidua $+\mathrm{MT})\left(\mathrm{mm}^{2}\right)$ & $1.250(0.148)$ & $1.341(0.160)$ & $1.337(0.087)$ & 0.8774 \\
\hline Extent in MT (\% of total extent area) & $30.28(3.95)$ & $13.98(3.01)^{\mathrm{a}}$ & $12.77(3.85)^{\mathrm{a}}$ & 0.0032 \\
\hline T-D extent overlap (\% of border length) & $78.59(7.09)$ & $82.11(3.14)$ & $81.89(5.65)$ & 0.8741 \\
\hline Decidua-MT extent overlap (\% of border length) & $59.58(7.14)$ & $32.63(6.31)^{\mathrm{a}}$ & $34.96(6.41)$ & 0.0151 \\
\hline
\end{tabular}

The data are presented as means (SEM). Statistical analysis.

${ }^{a}$ Indicates a significant difference from the wt saline group.

b Indicates a significant difference from the $d b /+$ saline group. 

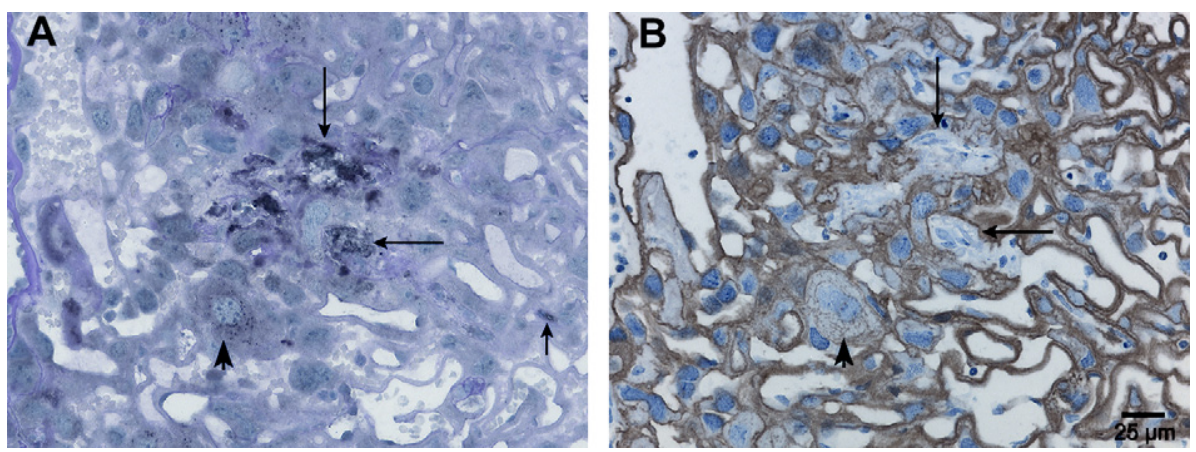

Fig. 2. Microscopic view of a labyrinthine region in a gd18.5 db/+ mouse treated with TNF from gd11.5. Note aggregations of apoptotic cells corresponding with villous stroma (long arrows), a solitary apoptotic cell (short arrow), and a large cytotrophoblastic cell (arrowpoint) showing positivity for cleaved caspase-3. A. Section stained for cleaved caspase-3 and $\alpha$-actin, counterstained with PAS. B. Parallel section stained for keratin.

humans) [29]. While the total placental area was slightly higher than in $w t$ mice, we found no hypertrophy of the trophospongium as observed in some diabetic rodent models [30].

\subsection{Apoptosis in gd18.5 db/+ placentas}

Compared with wt placentas, apoptosis was not upregulated in $d b /+$ placentas. However, systemic TNF administration in $d b /+$ dams during the last week of gestation (100-120 $\mu \mathrm{g} / \mathrm{kg}$ ) raised the number of apoptotic cells in both labyrinth and trophospongium. This pro-apoptotic effect was accompanied by a reduction in the number of fetuses and maternal weight gain. Thus, TNF administration in $d b /+$ mice replicates the adverse effect of high-fat diets on litter size in rats $[3,4]$.

Necrosis of the placenta was previously described in gd 18.5 rats after a single intraperitoneal injection of a higher dose of TNF $(500 \mu \mathrm{g} / \mathrm{kg}) 7$ days earlier [24]. Also, rats treated with a nitric oxide synthetase inhibitor from gd7.5 to gd13.5 showed a rise in serum TNF and in apoptotic cells in the trophospongium at gd19.5 [31].

TNF in the maternal circulation is expected to reach the base of the labyrinth through the centrally descending arterial canals, which branch off into highly anastomosing sinusoid spaces that extend radially outwards and back towards the trophospongium [32]. There is no evidence for transfer of maternal TNF to the fetal circulation, as would be anticipated for a small peptide (molecular weight: $17.4 \mathrm{kDa})$. In the dually perfused human placenta, no transfer was detected in either direction [33]. Intravenously injected ${ }^{125} \mathrm{I}$-TNF in gravid rats was immunoprecipitated in maternal tissues and placenta but not in fetal tissues [34].

We did not attempt a morphological identification of all apoptotic cells in the placenta in the three groups. Yet some apoptotic cells in the TNF-treated $d b /+$ mice were clearly localized in the cytokeratin-negative labyrinthine stroma. In addition, we identified apoptotic cytotrophoblasts. Of note, TNFR1 and TNFR2 are highly expressed in villous stromal cells and cytotrophoblasts [23].

\subsection{Apoptosis in gd18.5 db/+ placental bed}

More apoptotic cells were detected in the MT but not in the decidua of TNF-treated $\mathrm{db} /+$ dams. Part of the apoptotic cells in both compartments were identified as uNK cells. In the mouse placental bed, uNK cells emerge from gd6, accumulating until mid-gestation and then gradually disappearing through apoptosis, yet some cells persist at term and even postpartum [35-37]. Surprisingly, the MT contained the highest number of uNK cells in TNF-treated $d b /+$ dams. Since DNA synthesis in MT uNK cells stops at gd12.5 [35], TNF administration from gd11.5 is not expected to affect the initial uNK cell number in this compartment. Rather, the markedly higher number of uNK cells staining intensely positive for cleaved caspase3 suggests a suppressed clearance, while the higher number of
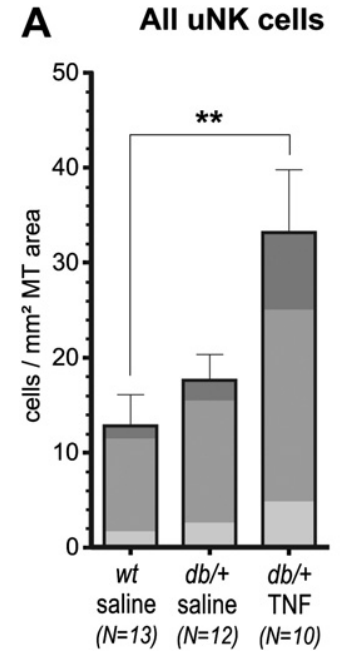

B

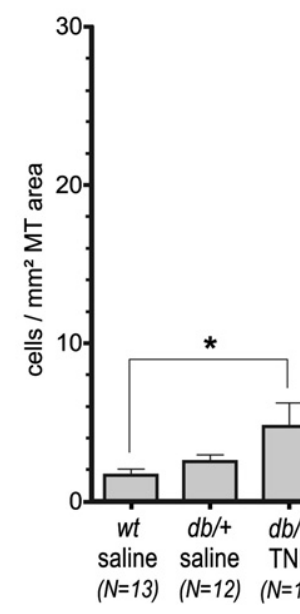

cleaved caspase 3 staining

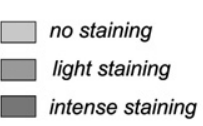

Fig. 3. Apoptosis in uNK cells in the mesometrial triangle (MT) of saline-treated $w t$ and $d b /+$ mice and TNF-treated $d b /+$ mice. All cell numbers were expressed as cells per mm ${ }^{2}$ of MT area. A. Total number of granulated uNK cells (ANOVA: $p=0.0064$ ). The relative numbers corresponding to the three staining categories are stacked within the bars. B. Granulated uNK cells stratified according to the intensity of cleaved caspase- 3 staining (ANOVA: $p=0.044$ for uNK cells without staining; $p=0.0517$ for lightly-stained uNK cells; $p=0.0001$ for intensely-stained uNK cells). Between-group differences are shown by ${ }^{*}(p<0.05),{ }^{* *}(p<0.01)$ or ${ }^{* * *}(p<0.001)$. 


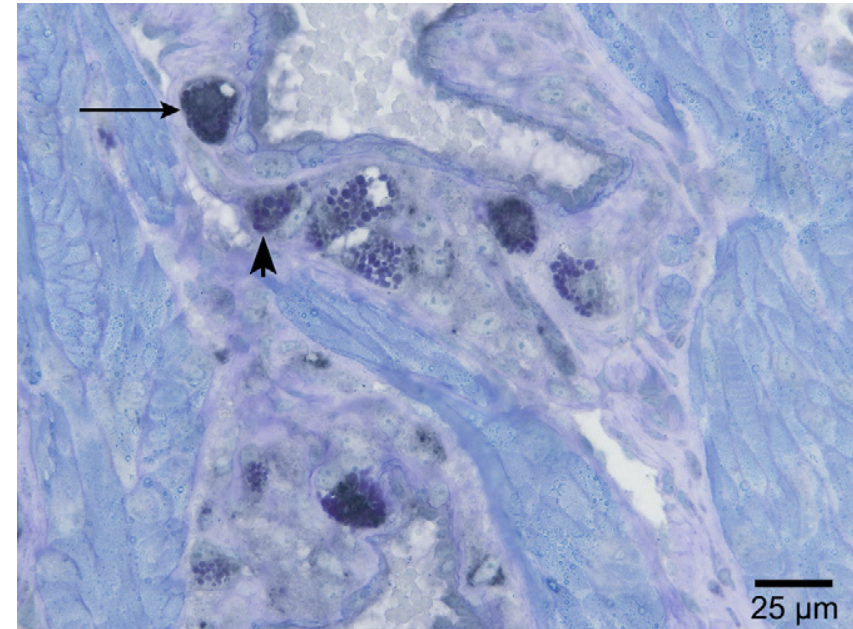

Fig. 4. Detail of an MT region in a gd18.5 db/+ mouse treated with TNF from gd11.5 Note the uNK cells with PAS-positive cytoplasmic granulation. Some of the uNK cells show intense (long arrow) or light (arrowpoint) co-staining for cleaved caspase-3 in brown-black.

negative cells might indicate a later onset of apoptosis. The mechanisms leading to these events are not clear at this moment. Persistence of MT uNK cells at gd 17.5 was previously reported in two animal models of pregestational diabetes [38]. Future studies should examine the effects of TNF on uNK cells at earlier stages of gestation. In concordance with previous studies [26,39], the majority of uNK cells in both decidua and MT were DBA-positive.

\subsection{Placental TNF}

Human uNK cells express TNF mRNA [40] but no data are available for the mouse. In the present study, TNF mRNA expression in both placenta and MT was comparable in the three groups. Nonetheless, MT TNF expression was slightly lower than placental expression in $w t$ but not in $d b /+$ mice, suggesting a relative TNF overexpression in MT of $d b /+$ dams. However, the small number of (pooled) MT samples precludes a conclusion at this stage.

There was no evidence of down- or upregulation of the TNF signaling apoptosis pathway in the placenta or MT of $d b /+$ mice treated with TNF, as shown by the comparable mRNA expression of the three key molecular markers Tradd, Traf2 and Fadd.

\subsection{Trophoblast invasion at gd18.5}

In our $w t$ mice, $30 \pm 4 \%$ of the trophoblastic cells in the placental bed were located in the MT. Previous findings obtained in gd17.5 mice suggested that trophoblast invasion is restricted to the decidua [41]. However, the daily progression of trophoblast invasion up to the end of gestation is not well documented in the mouse. In the rat, the day-to-day changes are considerable [27] and strain differences have been reported [42]. The depth of trophoblast invasion was inversely related to the increased number of uNK cells in some studies, and TNF may be among the uNK-derived signals mediating this association [41,42].

Trophoblast invasion was shallower in $d b /+$ uteri. Interestingly, leptin and insulin receptors are expressed in villous and extravillous trophoblasts of the human placenta and in the glandular epithelial cells of the decidua [43]. GDM increases the risk of pre-eclampsia, a condition characterized by shallow trophoblast invasion; increased circulating leptin and/or TNF have been proposed as possible mediators explaining this association [44]. However, in the present study, exogenous TNF did not perturb trophoblast invasion in $\mathrm{db} /+$ uteri. Follow-up studies might explore the implantation-site effects of TNF-blocking monoclonal antibodies [45] in $d b /+$ dams fed a standard or high-fat diet.

\subsection{Conclusions}

Leptin-resistant $d b /+$ dams demonstrated a shallower trophoblast invasion pattern at term, yet this pattern was not affected by s.c. administration of TNF during the last week of gestation. But exogenous TNF in $d b /+$ dams increased the number of apoptotic cells in the placental labyrinth and trophospongium, which may be related to a reduction of the number of fetuses and maternal weight gain. In addition, TNF-treated $d b /+$ mice harboured more residual uNK cells in the MT, and markedly more uNK cells showed intense staining for cleaved caspase-3.

\section{Conflict of interest}

The authors report no conflict of interest.

\section{Acknowledgements}

This work was supported by grant no. G.0285.07 from the Fonds voor Wetenschappelijk Onderzoek (FWO)-Vlaanderen (Belgium). The FWO did not interfere with any part of the study. R.A. Bobadilla was a senior scientist on sabbatical leave from the Escuela Superior de Medicina del Instituto Politécnico Nacional (Mexico), and was partly supported by ICYTDF and COFAA (Mexico).

\section{References}

[1] Ferrara A. Increasing prevalence of gestational diabetes mellitus: a public health perspective. Diabetes Care 2007;30(Suppl. 2):S141-6.

[2] Gardosi J, Francis A. A customized standard to assess fetal growth in a US population. Am J Obstet Gynecol 2009;201. 25.e1-7.

[3] Siemelink M, Verhoef A, Dormans JA, Span PN, Piersma AH. Dietary fatty acid composition during pregnancy and lactation in the rat programs growth and glucose metabolism in the offspring. Diabetologia 2002;45:1397-403.

[4] Buckley AJ, Keserü B, Briody J, Thompson M, Ozanne SE, Thompson $\mathrm{CH}$ Altered body composition in the male offspring of high fat-fed rats. Metabolism 2005;54:500-7.

[5] Akyol A, Langley-Evans SC, McMullen S. Obesity induced by cafeteria feeding and pregnancy outcome in the rat. Br J Nutr 2009;162:1601-10.

[6] Jungheim ES, Schoeller EL, Marquard KL, Louden ED, Schaffer JE, Moley KH. Diet-induced obesity model: abnormal oocytes and persistent growth abnormalities in the offspring. Endocrinology 2010;151:4039-46.

[7] Liang C, DeCourcy K, Prater MR. High-saturated-fat diet induces gestationa diabetes and placental vasculopathy in C57BL/6 mice. Metabolism 2010;59: 943-50.

[8] Caluwaerts S, Holemans K, van Bree R, Verhaeghe J, Van Assche FA. Is lowdose streptozotocin in rats an adequate model for gestational diabetes mellitus? J Soc Gynecol Investig 2003;10:216-21.

[9] Kaufmann RC, Amankwah KS, Dunaway G, Maroun L, Arbuthnot J, Roddick JW. An animal model of gestational diabetes. Am J Obstet Gynecol 1981;141:479-82.

[10] Lambin S, van Bree R, Caluwaerts S, Vercruysse L, Vergote I, Verhaeghe J. Adipose tissue in offspring of Lepr $^{d b /+}$ mice: early-life environment vs. genotype. Am J Physiol Endocrinol Metab 2007;292:E262-71.

[11] Ishizuka T, Klepcyk P, Liu S, Panko L, Liu S, Gibbs M, et al. Effects of overexpression of human GLUT4 gene on maternal diabetes and fetal growth in spontaneous gestational diabetic C57BLKS/J Lepr ${ }^{d b /+}$ mice. Diabetes 1999;48: 1061-9.

[12] Yamashita $\mathrm{H}$, Shao J, Ishizuka T, Klepcyk PJ, Muhlenkamp P, Qiao L et al. Leptin administration prevents spontaneous gestational diabetes in heterozygous Lepr ${ }^{d b /+}$ mice: effects on placental leptin and fetal growth. Endocrinology 2001;142:2888-97.

[13] Lawrence S, Warsaw J, Nielsen HC. Delayed lung maturation in the macrosomic offspring of genetically determined diabetic $(\mathrm{db} /+)$ mice. Pediatr Res 1989;25:173-9.

[14] Winkler G, Cseh K, Baranyi É, Melczer Z, Speer G, Hajós P, et al. Tumor necrosis factor system in insulin resistance in gestational diabetes. Diabetes Res Clin Pract 2002;56:93-9.

[15] Kirwan JP, Hauguel-De Mouzon S, Lepercq J, Challier J-C, Huston-Presley L Friedman JE, et al. TNF- $\alpha$ is a predictor of insulin resistance in human pregnancy. Diabetes 2002;51:2207-13. 
[16] Radaelli T, Varastehpour A, Catalano P, Hauguel-de Mouzon S. Gestational diabetes induces placental genes for chronic stress and inflammatory pathways. Diabetes 2003;52:2951-8.

[17] Verhaeghe J, van Bree R, Lambin S, Caluwaerts S. Adipokine profile and C-reactive protein in pregnancy: effects of glucose challenge response versus body mass index. J Soc Gynecol Investig 2005;12:330-4.

[18] McLachlan KA, O'Neal D, Jenkins A, Alford FP. Do adiponectin, TNF $\alpha$, leptin and CRP relate to insulin resistance in pregnancy? Studies in women with and without gestational diabetes, during and after pregnancy. Diabetes Metab Res Rev 2006;22:131-8.

[19] Altinova AE, Toruner F, Bozkurt N, Bukan N, Karakoc A, Yetkin I, et al. Circulating concentrations of adiponectin and tumor necrosis factor- $\alpha$ in gestational diabetes mellitus. Gynecol Endocrinol 2007;23:161-5.

[20] Weisberg SP, McCann D, Desai M, Rosenbaum M, Leibel RL, Ferrante AW. Obesity is associated with macrophage accumulation in adipose tissue. J Clin Invest 2003;112:1796-808.

[21] Lang CH, Dobrescu C, Bagby GJ. Tumor necrosis factor impairs insulin action on peripheral glucose disposal and hepatic glucose output. Endocrinology 1992;130:43-52.

[22] Hotasmisligil GS, Shargill NS, Spiegelman BM. Adipose expression of tumor necrosis factor- $\alpha$ : direct role in obesity-linked insulin resistance. Science 1993;259:87-91.

[23] Haider S, Knöffler M. Human tumour necrosis factor: physiological and pathological roles in placenta and endometrium. Placenta 2009;30:111-23.

[24] Silen ML, Firpo A, Morgello S, Lowry SF, Francus T. Interleukin- $1 \alpha$ and tumor necrosis factor $\alpha$ cause placental injury in the rat. Am J Pathol 1989;135: 239-44.

[25] Lambin S, van Bree R, Vergote I, Verhaeghe J. Chronic tumor necrosis factor$\alpha$ infusion in gravid C57BL6/J mice accelerates adipose tissue development in female offspring. J Soc Gynecol Investig 2006;13:558-65.

[26] Yadi H, Burke S, Madeja Z, Hemberger M, Moffett A, Colucci F. Unique repertoire in mouse uterine NK cells. J Immunol 2008;181:6140-7.

[27] Vercruysse L, Caluwaerts S, Luyten C, Pijnenborg R. Interstitial trophoblast invasion in the decidua and mesometrial triangle during the last third of pregnancy in the rat. Placenta 2006;27:22-33.

[28] Hemmeryckx B, van Bree R, Van Hoef B, Vercruysse L, Lijnen HR, Verhaeghe J. Adverse adipose phenotype and hyperinsulinemia in gravid mice deficient in placental growth factor. Endocrinology 2008;149:2176-83.

[29] Widdowson EM. Chemical composition of newly born mammals. Nature 1950;166:626-8

[30] Yu Y, Singh U, Shi W, Konno T, Soares MJ, Geyer R, et al. Influence of murine maternal diabetes on placental morphology, gene expression, and function. Arch Physiol Biochem 2008;114:99-110.
[31] Tsukimori K, Komaztsu H, Fukushima K, Kaku T, Nakano H, Wake N. Inhibition of nitric oxide synthetase at mid-gestation in rats is associated with increases in arterial pressure, serum tumor necrosis factor- $\alpha$, and placental apoptosis. Am J Hypertens 2008;21:477-81.

[32] Adamson SL, Lu Y, Whiteley KJ, Holmyard D, Hemberger M, Pfarrer C, et al. Interactions between trophoblast cells and the maternal and fetal circulation in the mouse placenta. Dev Biol 2002;250:358-73.

[33] Aaltonen R, Heikkinen T, Hakala K, Laine K, Alanen A. Transfer of proinflammatory cytokines across term placenta. Obstet Gynecol 2005;106:802-7.

[34] Carbó N, López-Soriano FJ, Argilés JM. Tumour necrosis factor- $\alpha$ does not cross the rat placenta. Cancer Lett 1998;128:101-4.

[35] Peel S. Granulated metrial gland cells. Adv Anat Embryol Cell Biol 1989;115: $1-112$.

[36] Delgado SR, McBey B-A, Yamashiro S, Fujita J, Kiso Y, Croy BA. Accounting for the peripartum loss of granulated metrial gland cells, a natural killer cell population, from the pregnant mouse uterus. J Leukoc Biol 1996;59:262-9.

[37] Wang C, Umesaki N, Nakamura H, Tanaka T, Nakatani K, Sakaguchi I, et al. Expression of vascular endothelial growth factor by granulated metrial gland cells in pregnant murine uteri. Cell Tissue Res 2000;300:285-93.

[38] Phichitrasilp T, Hondo E, Rerkamnuaychoke W, Wakitani S, Sugiyama M, Terakawa J, et al. Reproductive performance in diabetes mice with a special reference to uterine natural killer cells and placental growth factor. J Vet Med Sci 2009;71:519-23.

[39] Zhang JH, Yamada AT, Croy BA. DBA-lectin reactivity defines natural killer cells that have homed to mouse decidua. Placenta 2009;30:968-73.

[40] Jokhi PP, King A, Sharkey AM, Smith SK, Loke YW. Screening for cytokine messenger ribonucleic acids in purified human decidual lymphocyte populations by the reverse-transcriptase polymerase chain reaction. J Immunol 1994;153:4427-35.

[41] Ain R, Canham LN, Soares MJ. Gestation stage-dependent intrauterine trophoblast cell invasion in the rat and mouse: novel endocrine phenotype and regulation. Dev Biol 2003;260:176-90.

[42] Konno T, Rempel LA, Arroyo JA, Soares MJ. Pregnancy in the brown Norway rat: a model for investigating the genetics of placentation. Biol Reprod 2007;76:709-18.

[43] Toth B, Fischl A, Scholz C, Kuhn C, Friese K, Karamouti M, et al. Insulin and leptin as possible new candidates for endocrine control in normal and disturbed human pregnancy. Mol Hum Reprod 2009;15:231-9.

[44] Seely EW, Solomon CG. Insulin resistance and its potential role in pregnancyinduced hypertension. J Clin Endocrinol Metab 2003;88:2393-8.

[45] Araújo EP, De Souza CT, Ueno M, Cintra DE, Bertolo MB, Carvalheira JB, et al. Infliximab restores glucose homeostasis in an animal model of diet-induced obesity and diabetes. Endocrinology 2007;148:5991-7. 